\title{
Galectins as Molecules of Danger Signal, which could Evoke an Immune Response to Infection
}

\author{
ガレクチン一感染時に免疫反応を誘起する“Danger Signal” を送ることのできるレクチン
}

\author{
Sato, Sachiko \\ Glycobiology Laboratory, Centre de Recherche en Infectiologie du CHUL, \\ 2705 boul. Laurier, Ste-Foy, Québec, Canada, G1V 4G2 \\ FAX: 418-654-2715, E-mail: Sachiko.Sato@crchul.ulaval.ca
}

Key Words : cytokine, danger signal, galectin, infectious disease, innate immunity

\begin{abstract}
Galectins are members of a family of proteins defined by their conserved peptide sequence elements, which are crucial for their affinities to $\beta$-galactosides. Unlike other lectins, galectins are cytosolic proteins but can be actively secreted from inflammatory macrophages and can also be passively released when cells expressing galectins are damaged. In recent years, numbers of papers have demonstrated that galectins can act as immunomodulators or proinflammatory factors, implying their roles in immunity against infections. In the initial stage of infection, innate immunity must recognize invasive infections and initiate a defence system efficiently to clear the infection without the aid of acquired immunity. Until recently, discrimination between self and nonself by innate immunity has been considered as the most important element, which can trigger immunity against infections. A novel model, called 'the Danger model', has been proposed recently and has since gained much attention and support as the initial recognition mechanism for infection. In the Danger model, innate immunity is more concerned with damage induced by invading pathogens than with the 'foreignness' of invading pathogen, immunity is then called into action by alarm signals (danger signals) from injured cells. As galectins can be considered as a new type of proinflammatory factors, secretion and release of which is closely associated with the timing in which the immune system is required to send 'danger signals', in this review, the potential roles of galectins as molecules of danger signals will be discussed.
\end{abstract}

要 約

ガレクチンは、 $\beta$-ガラクトシドに親和性のある遺伝的に保 存されたペプチド配列を分子内に有することで定義される一連 のタンパク質である。ガレクチンは他のレクチンとは異なり、 通常は細胞質に存在している。細胞質タンパク質であるにも関 わらず、ガレクチンは炎症性マクロファージによって能動的に 分泌、もしくは損傷を受けたガレクチン発現細胞から受動的に 放出される。近年の研究からガレクチンが免疫調節活性や炎症 誘発活性を有することが示唆されており、ガレクチンが感染時 の免疫反応において重要な㗢きを担っていることが推察され る。感染初期においては、先天性免疫は侵入した病原体を獲得 免疫の助けなしに感知し、その病原体を除くために防御機構を 始動させなければならない。病原体に対する防御を始動するた めには、先天性免疫によって自己と非自己を区別して認識する ことが最も重要であると近年まで考えられていた。この説に対 し “Danger signal” 説が最近提唱され、感染の初期認識を行う機 構として注目と支持を集めている。“Danger signal”説によれ ば、先天性免疫は、侵入する病原体が非自己であることよりも むしろ侵入する病原体によって引き起こされた損傷を認識す る。そして損傷した細胞からのアラームシグナル( “Danger signal”)によって防御を開始する。ガレクチンは免疫系が “Danger signal”を送るべきタイミングに付随して分泌、または 放出されるような新しい型の炎症誘発因子と考えられるため、 本総説では “Danger signal” 分子としてのガレクチンの役割につ いて仮説を提唱したいと思う。

\section{A. The Danger Model and Cytoplasmic Galectins}

Our immune system is composed of innate immunity and acquired immunity, which are responsible for the protection against pathogen invasion into our body. Thus, the immune defense system is initiated when the immunity recognizes such invasion. What initiates our immunity system? Recent advances
A. “Danger signal” 説と細胞質に存在するガレクチン

病原体の侵入から我々の体を防御する免疫機構は先天性免 疫と獲得免疫からなる。病原体の体内への侵入を感知した時に 免疫防御機構が作動するが、我々の免疫系はどのようにして作 動するのだろうか。最近の免疫学の進歩から 2 つのモデルが提 
in immunology have resulted in the development of two models; one model based on the self-nonself discrimination (1) and the Danger model (2). In the concept of self-nonself model of immunity (3), immunity is initiated when lymphocytes recognize the invasion of a 'nonself' entity such as a pathogen with the aid of antigen presenting cells. The response can also be initiated by the innate immunity system, in which the nonself entity is recognized by phagocytic leukocytes (macrophages, dendritic cells and possibly neutrophils) through Toll-like receptors, and humoral molecules such as complement molecules and collectins. Collectins are C-type lectins, which can distinguish between the glycans that decorate self glycoproteins and the glycans expressed on the surface of pathogens (4). In contrast to the classical self-nonself model, the Danger model, elaborated by Matzinger in 1994 (2), proposes that our immune system is more concerned with the damage and the destruction caused by the entity -in the case of infection, pathogen - than the foreignness of the invading entity $(5,6)$. Thus, the crucial element in this Danger model is cell destruction, which then triggers the evocation of a cascade of immune responses, including recruitment of leukocytes to the affected sites. The release of intracellular molecules from the damaged cells is one of the results of cell destruction and there is a growing list of such intracellular molecules which can potentially initiate immune responses, including DNA (7), RNA (5), cytoplasmic heat shock proteins (8), hem (9) and thioredoxin (10). Notably, recent sets of data indicate that various lectins that are present in the cytoplasm can also trigger such immune responses (11-13).

Galectins are $\beta$-galactoside binding lectins that are found in the cytoplasm of various cells, including phagocytic leukocytes, endothelial cells and thymic epithelial cells (14-19). Although galectins are not sorted into the classical secretory pathway, it has been well established that galectins are released from cells. As discussed below, galectin release is often regulated in a differentiation or activation-dependent manner (20). Moreover, the cytoplasmic location (thus free from the majority of galectin's oligosaccharide ligands) serves as a unique reservoir of galectin, which can release the lectins when cells are damaged by infections. As recent evidence indicates that galectins are potential immunomodulators in various immune responses, in this review I would like to try to shed light on and discuss the roles of galectins as Danger signal molecules, which could be

\footnotetext{
${ }^{1}$ Recent work reveals that intracellular galectin- 3 can act as an antiapoptotic protein, possibly through a mechanism involving the prevention of cytochrome $\mathrm{C}$ release from mitochondria (21). In galectin-3 knock out mice, it appears that galectin- 3 deficiency in macrophages results in increased tendency to apoptosis (22). In contrast to macrophages, Colnot suggests that galectin-3 does not participate actively in the regulation of apoptosis of granulocytes (23). Thus, roles of galectin3 as antiapoptotic protein may vary depending on the cell types, but such intracellular roles should also contribute to the regulation of immunity.
}

唱されている。1つは自己と非自己の認識を要とするモデルで あり(1)、もう1つは “Danger signal” 説と呼ばれるモデルであ る(2)。自己一非自己認識モデル(3)では、リンパ球が抗原提示細 胞の介助のもとで病原体などの非自己物質の侵入を認識した時 に免疫機構が作動するとされている。この応答は先天性免疫機 構のみによっても誘起される。この場合、非自己物質は、Tolllike receptor を介して、あるいは補体やコレクチンなどの体液性 の分子を介して領食細胞（マクロファージ、樹状細胞、好中 球）に認識される。コレクチンはC 型レクチンであり、我々の 自己細胞表面の糖鎖と病原体上に表現されている糖鎖を見分け ることができる(4)。古典的な自己一非自己モデルとは対照的 に、1994年に Matzingerにより提唱された“Dangerモデル”に よれば、我々の免疫機構は侵入したものが非自己であるという ことよりも、むしろ感染によって引き起こされた組織の損傷ま たは破壊に対して応答する(2)。したがって、“Dangerモデル” に扔ける決定的な要素は細胞の破壊であり、これが白血球の感 染巣への遊走などの免疫反応カスケードを始動させる。細胞破 壊の結果として傷害された細胞から細胞内分子が放出される が、細胞内分子でこのように免疫応答を作動させ得るようなも のが多数報告されている(5、6)。DNA(7)やRNA(5)、熱ショック タンパク質(8)、へム(9)、チオレドキシン(10)などである。興味 深いことであるが、最近の一連のデータから細胞内に存在する 多様なレクチンも同様に免疫応答を誘起することができること が示されている(11-13)。

ガレクチンは、領食白血球や血管内皮細胞、胸腺上皮細胞 などの細胞内にある $\beta$-ガラクトシド結合タンパク質である(14 19)。ガレクチンは通常の分泌タンパク質のように細胞内の分泌 経路に入らないにもかかわらず、細胞外に放出されることがわ かっている。以下で述べるが、ガレクチンの細胞外への分泌は 分化あるいは活性化状態に依存して制御されている(20)。さら に、ガレクチンが細胞質に存在する（したがって、細胞内に あっては複合糖鎖を含むガレクチンのリガンドから隔離されて いる) ので、この細胞質はガレクチンの貯蔵庫となる。感染な どで細胞が損傷を受けた時にはガレクチンがこの貯蔵庫から放 出されるであろう。最近の研究ではガレクチンが種々の免疫反 応に扔いてその免疫調節因子となる可能性が示されているた め、本総説では、ガレクチンが感染時に細胞外に分泌され免疫

1最近の研究から、細胞質内のガレクチン-3 は抗アポトーシスタンパク 質として機能することがわかっている。これはおそらくミトコンドリア からのシトクロム Cの放出を阻害することによるものである(21)。ガレ クチン-3 欠損マウスを用いた実験では、マクロファージにおけるガレク チン-3の欠損はアポトーシスの頻度を高める(22)。これに対しColnot は ガレクチン-3 は好中球のアポトーシス調節には積極的に関与していない ことを示唆している(23)。ガレクチン-3 の抗アポトーシス活性は細胞の 種類により異なるようだが、このような細胞内での役割は免疫機構の調 節に寄与するものである。 
evocative of an immune response to infection. Thus, some of galectins' extracellular biological functions related to immunity will be reviewed but I will not be able to cover the potential intracellular roles of galectins in the immune system ${ }^{1}$ or extracellular roles of galectins in non-immune systems. Readers would be recommended to look at the recent reviews on galectins on those functions (14-19).

\section{B. Structures of Galectins}

Galectins belong to a $\beta$-galactoside binding protein family defined by the conserved peptide sequence elements involved in the carbohydrate binding activity of those lectins (24). Up to fourteen galectins (galectin-1-14) have been found in mammals so far as well as many in other phyla including birds, amphibians, fish, nematodes, Drosophila, sponges and fungi (1419,25-28). While all galectins share a core sequence (carbohydrate recognition domain CRD) consisting of -130 amino acids, galectins exhibit interesting structural differences in the presentation of the CRD (Fig. 1). While some galectins contain one CRD (prototype), and exist as monomers (galectin-5, 7,10 ) or dimers (galectin-1, 2, 11, 13, 14), other galectins, such as galectin-4, 6, 8, 9, 12 contain two CRD connected by a short linker region (tandem repeat) (29). In contrast, galectin-3 uniquely occurs as a chimeric protein with one CRD and an additional non-CRD domain, which is involved in the oligomerization of galectin-3 (30-32).

Regardless of the presentation of the CRD in the galectin molecule, galectins can cross-link their ligands (Fig. 2) because the majority of galectins are intrinsically divalent (with the exception of galectin-3, 5, 7, and 10). Galectin-3, which exists as a monomer, also mediates cross-linking of its ligands through its oligomerization. Upon binding to its glycoconjugate ligands at the cell surface, the conformation of galectin- 3 appears to be altered in a concentration and time-dependent manner, and galectin-3 begins to oligomerize through the self-assembly of the $N$-terminal regulatory domain of the galectin- 3 molecules $(31,32)$. It has been suggested that $C$-terminal domain of galectin-3 is also implicated in the oligomerization (33). The
反応を誘起する“Danger signal”を送ることのできるレクチンで ある、という観点から考察を行ってみたい。したがって、免疫 系に扔ける細胞内ガレクチンの役割1、及び、免疫系以外におけ るガレクチンの細胞外での役割については本総説では残念なが ら紹介できない。これらの機能については最近のガレクチンの 総説を参照されたい(14-19)。

\section{B. ガレクチンの構造}

ガレクチンは、糖鎖認識活性に必要な保存されたぺプチド配 列を有することで定義される $\beta$-ガラクトシド結合タンパク質の ファミリーの一員である(24)。哺乳動物においては現時点で14種 のガレクチンが見い出されており、鳥、再生類、魚、線虫、 ショウジョウバエ、海綿、カビといったその他の門に扔いても 存在が確認されている(14-19、25-28)。すべてのガレクチンは、 約130アミノ酸からなる糖鎖認識ドメイン (carbohydrate recognition domain, CRD) を含むが、興味深いことに、CRDのガレクチ ン分子内における配置は異なっている(Fig. 1)。プロト型のガレ クチンは 1 分子に 1 個の CRD を含み、単量体（ガレクチン-5、

6、7）あるいは二量体（ガレクチン-1、2、11、13、14）として 存在する。タンデムリピート型のガレクチンは 2 個の CRD が短 いリンカーによりつながって存在する(29)。これらのガレクチン と異なり、ガレクチン-3 はキメラ型であり、1 分子に 1 個の CRD と、分子の多量体形成の鍵をにぎる非 CRD ドメインから なっている(30-32)。

分子内における CRD の配置の違いに関わらず、ガレクチン は細胞表面の糖タンパク質リガンドを架橋することができる (図 2)。これは多くのガレクチンがもともと 2 価であることによる （ガレクチン-3、5、7、10は例外）。ガレクチン-3は通常単量体 として存在するが、多量体化してリガンドを架橋することがで きる。細胞表面上の複合糖鎖リガンドに結合するとガレクチン3 は濃度および時間依存的にその立体構造を変化させるが、その 結果、 $\mathrm{N}$ 末端の非 CRD 部位である調節ドメインを介してこれが 多量体化し $(31 、 32) 、 C R D を$ 数個（主に 2 個）もつ分子を形成す るということがその理由である。このガレクチン-3の多量体化 には C 末端ドメインも関与していることが明らかになっている

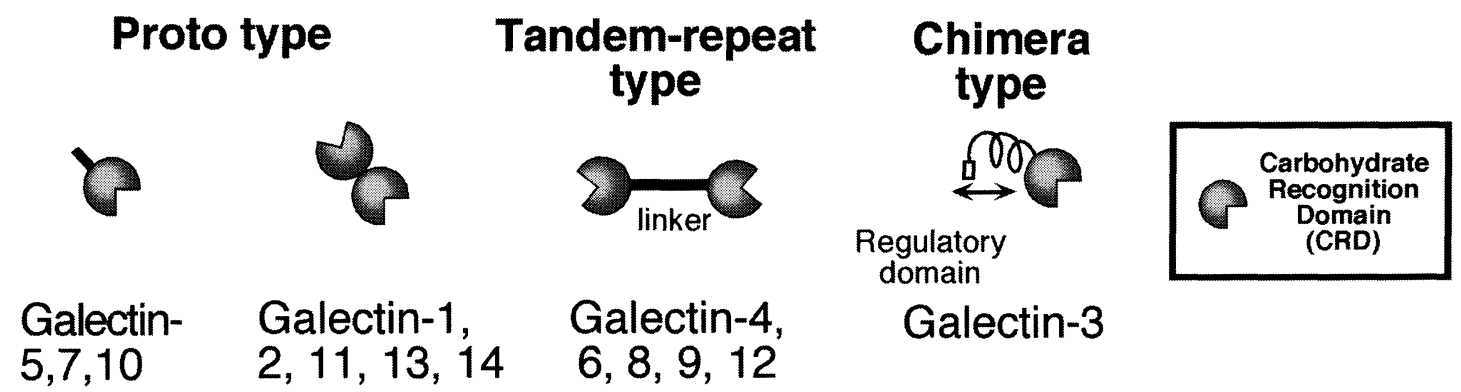

Fig. 1. Galectin structures. 


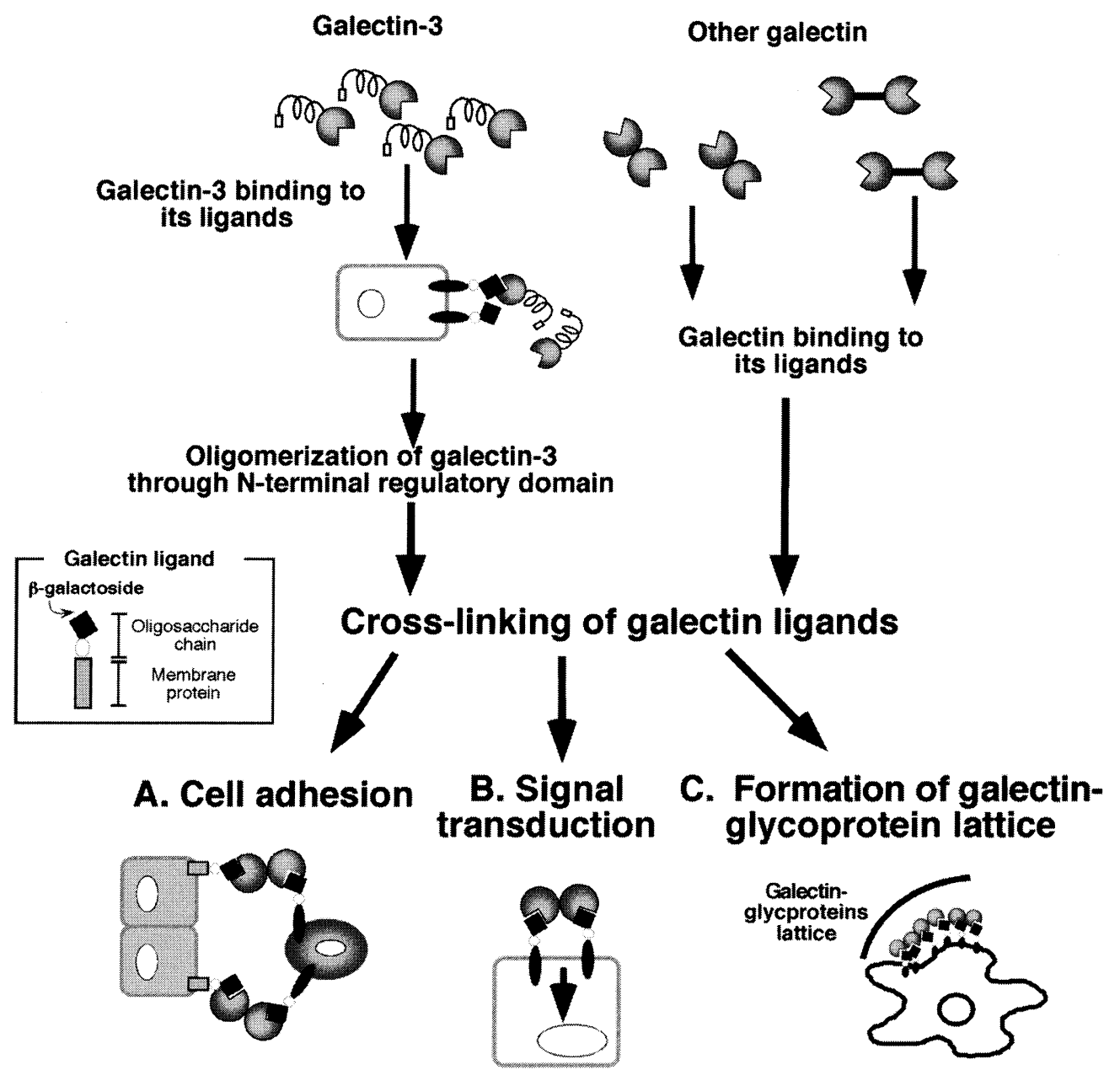

Fig. 2. Different cellular effects induced by galectin-mediating cross-link of galectin ligands on cell surfaces. Cross-linking of galectin ligands expressed on cells results in cell-cell adhesion (A) triggering signal transduction (B) or the formation of surface multivalent galectin lattice (C).

oligomerization results in the formation of a galectin-3 molecule which possesses multivalent CRDs. This dynamism between monomer and oligomer to regulate 'lectin activity' (activity to cross-link ligands) is a very unique feature of galectin-3, as the majority of galectins do not alter their multivalency.

Once they are released extracellularly, galectins could cross-link their surface glycoprotein ligands (Fig. 2). As discussed later, the cross-linking of galectin ligands induces various activities, including cell adhesion (Fig. 2A), signal transduction through receptor clustering (Fig. 2B) and the formation of multivalent galectin-glycoprotein lattices on cell surface, which could negatively regulate the movement of surface receptors (Fig. 2C) (16-19). Many of those reported functions of galectins are closely related to immunity, implying the roles played by galectins during infection. However, in order to crosslink surface ligands to exert their activities, galectins, the majority of which are found in the cytoplasm, have to be released extracellularly (20).
(33)。多量体化によりガレクチン-3 分子は多価の CRD を有する ようになる。大多数のガレクチンでは価数が変化することがな いため、単量体型から多量体型に変化してレクチン活性（架橋 型リガンドに対する結合活性）を動的に制御するのはガレクチ ン-3 特有の性質である。

ガレクチンは細胞外に放出された後、細胞表面の糖タンパ ク質リガンドを架橋することができる(図 2)。後で議論するが、 ガレクチンリガンドの架橋により、細胞接着(図 $2 \mathrm{~A}$ )、受容体の 架橋によるクラスター形成を介したシグナル伝達(図 2B)、細胞 表面の受容体の側方拡散を抑制する細胞表面上の多価のガレク チン-糖タンパク質の格子の形成(図 2C)といった種々の生物活性 が誘導される(16-19)。これまでに報告されたガレクチンの活性 の多くは免疫反応に密接に関わっており、感染過程におけるガ レクチンの役割を示唆している。しかしながら、上記の活性を 誘導するような細胞表面リガンドの架橋が生じるためには、細 胞質内に存在するガレクチンが細胞外に放出されることが必要 である(20)。 


\section{Extracellualr Release of Galectins; Passive Release and Active Secretion}

Since it is known that galectins are found in the extracellular space and at the cell surface, galectin molecules have to be exported from those cells (20). The majority of the secretory proteins contain either signal sequences or potential transmembrane domains, which are essential in order for them to be sorted to the secretory pathway for secretion. However, most members of the galectin family ${ }^{2}$ do not contain any of those sequences. Thus, galectin molecules are synthesized on free ribosomes and first accumulate in the cytosol $(20,35,36)$. There could be at least two ways for cytosolic molecules to be released; release caused by cell necrosis (passive release) and active secretion from live cells through 'leaderless' (alternative) secretory pathway (see below for details), as it is proposed in the case of some cytoplasmic cytokines or cytokine-like molecules proteins, such as interleukin (IL)-1 (37-39), fibroblast growth factors (FGF) (40-42), thioredoxin (43) and possibly some of the $S 100$ protein family (44).

In chronic or severe acute infections, various cells could be damaged by exudated leukocytes or infectious agents, resulting in the release of cellular contents. Thus, in some cases of severe infections, cell necrosis could result in passive release of intracellular components such as galectins. Interestingly, release of some cytoplasmic molecules, such as thioredoxin, IL1 , heat shock proteins (HSPs) and calreticulin are recognized by immunity as 'danger signals' and those molecules can trigger various immune responses $(8,10,45)$. As galectins also play roles as immunomodulators (see details below), it is likely that some of the galectin molecules can be released through necrosis at the infected sites by this passive mechanism and those extracellular galectin molecules could also serve as 'danger signals'.

Historically speaking, it had been casually postulated by the majority of the immunology community, that cytosolic cytokines, such as IL-1 and fibroblast growth factors are released by this passive mechanism, which is triggered by cell necrosis, but not by active secretion. However, various lines of investigation over the secretion mechanism of IL-1 and FGF have now established the solid bases that cells are able to actively secrete some cytosolic cytokines through the 'leaderless' secretory pathway, without compromising membrane integrity (20).

Active secretion of galectins (galectin-1, 3 and 9) from live cells has also been well demonstrated by various reports $(20,46)$. It appears that galectin-3 utilizes, at least in part, the same 'leaderless' secretory pathways that is used by FGF and IL-1 (20). The secretion of galectins is regulated in a differentiation-dependent manner $(36,47-49)$. For example, we, as well as others, have demonstrated that inflammatory macrophages

${ }^{2}$ A recent report suggesting that alternative spliced forms of galectin3 which contains transmembrane domain have been detected in chicken osteoblast-like cells and intestine (34).
C. ガレクチンの細胞外放出一受動的放出と能動的分泌

ガレクチンは細胞外部分や細胞表面にも認められるため、 この分子はガレクチン産生細胞から細胞外へ運び出される必要 がある $(20)$ 。大多数の分泌タンパク質にはシグナルペプチドもし くは膜貫通ドメインがあり、分子が分泌経路ヘソートされるた めにこれらの存在が必要である。しかしながら、ガレクチン ファミリーのほとんどはこのような配列を含まない2。したがっ て、ガレクチン分子は遊離型リボゾームで合成されてまず細胞 質に蓄積される(20、35、36)。それにもかかわらず、ガレクチンは 細胞外部分や細胞表面に存在しているので、通常の分泌経路を 経ずに細胞から放出されているものと考えられている(20)。細胞 質内の分子が放出される経路として少なくとも2 通りのものが あり得る。細胞のネクローシスの結果として起きる受動的な放 出、及び“リーダレス”（オルタナティブ）分泌経路を介する 能動的な分泌である（詳細は以下に記す）。この“リーダレ ス”分泌経路については、インターロイキン-1 (IL-1, 37-39)、 繊維芽細胞増殖因子(FGF, 40-42)、チオレドキシン(43)、S100プ ロテインファミリーの一部(44)のような細胞質内サイトカインや サイトカイン様分子の分泌にも関与していることが指摘されて いる。

慢性感染症や重篤な急性感染症の病巣では血管から浸出し た白血球や感染菌などにより種々の細胞が損傷を受け、ここか ら細胞内成分が放出される。重篤な感染時には細胞のネクロー シスによってガレクチンなどの細胞内成分が受動的に放出され ることが考えられる。興味深いことに、細胞外に放出される細 胞質内タンパク質、例えばチオレドキシン、熱ショックタンパ ク質、カルレティキュリンは免疫機構により “Danger signal” と して認識され、種々の免疫反応を誘発する $(8,10,45)$ 。ガレクチン も免疫調節因子として作用する（以下で述べる）ため、ガレク チン分子の一部は感染部位のネクローシスによって受動的に放 出され、細胞外で同様に “Danger signal” の一つになるものと考 えられる。

歴史的には、免疫学者の大多数は IL-1 やFGF などの細胞 質内サイトカインが能動的な分泌ではなく、ネクローシスで始 動する受動的な機構で放出されると考えていた。しかし、IL-1 やFGF の分泌機構についての研究から、これらの細胞質内サイ トカインは“リーダレス”分泌経路を介して、細胞膜の損傷を 伴わずに能動的に分泌されることが明らかにされている $(20)$ 。

ガレクチン（ガレクチン-1、3、9）が生細胞から能動的に 分泌されることは多数の研究から示されている $(20,46)$ 。ガレク チン-3 は FGF や IL-1で使用されるのと同じ“リーダレス”分 泌経路の少なくとも一部を利用していた $(20)$ 。ガレクチンの分泌 は分化依存的に調節されている(36、47-49)。例えば、腹腔内への チオグリコレート注入により腹腔に浸潤する炎症性マクロ ファージは、全細胞におけるガレクチン-3 の約 40\%を細胞外に

2最近の報告によると、トリの骨芽様細胞及び腸において膜貫通ドメイン を有するガレクチン-3のオルタナティブスプライシング体の存在が示唆 されている(34)。 
that are exudated to peritoneal cavities by thioglycollate secrete $-40 \%$ of their total galectin-3, while peritoneal resident macrophages, monocytes and alveolar macrophages are unable to secrete galectin-3 actively and retain it intracellularly $(48,50,51)$. From the point of view that galectin-3 acts as a potential molecule to send 'danger signals', the differentiation-specific secretion of galectin-3 from macrophages is intriguing. When infectious pathogens or some stimulants are introduced in the body, the first population of leukocytes to be recruited at the affected sites are not inflammatory macrophages but neutrophils, which are able to control the majority of mild infections such as E. coli infections. Interestingly, it appears that neutrophils ${ }^{3}$ cannot secrete galectin-3 through the leaderless secretory pathway leaving very little extracellular galectin-3 available (51). In contrast to neutrophils, "activated" inflammatory macrophages, which can secrete galectin-3 $(48,52,53)$, generally emigrate to the affected sites when the infections are persistent and have not been controlled by the exudated neutrophils $(23,54-56)$. Thus, the emigration of inflammatory macrophages itself is one of the situations where our primary defense system is to send the 'danger signals' to the general immunity for further protection. Since galectin-3 is actively secreted from inflammatory macrophages but not from resident peritoneal macrophages, such strict control of galectin's secretion could also be a clear indication that galectins are molecules of 'danger signals' for the innate immunity.

\section{Potential Galectins' Ligands Involved in Immune Re- sponses}

Once galectins are secreted or released extracellularly, galectins bind to their ligands, which are expressed on the cell surface (Fig. 2). While galectins were categorized as $\beta$-galactoside binding lectin, the majority of galectins, with the exception of galectin-10 (57), show a preference for lactose $/ N$ acetyllactosamine (Gal $\beta 1-3(4) \mathrm{Glc}(\mathrm{NAc})$ ) structures which are ubiquitously found in mammalian cells (16-19). Studies on the protein structures of galectins have also revealed that the carbohydrate binding pockets of the CRD differ among galectins; for example, galectin-3 appears to have an extended binding pocket compared to galectin-1 (58-60). Such a structural difference could be related to the different carbohydrate binding specificity observed among galectins; extension at the non-reducing terminal lactosamine units with Gal $\alpha 1-3$, GalNAc $\alpha 1-3$, Fuc $\alpha 1-2$ or Neu5Ac $\alpha 2-3$ substituents enhances affinity to some galectins such as galectin-3 but has a lesser effect or reduces binding of others, such as galectin-1 (61-63). Hence, some of the surface glycoconjugate ligands could be recognized by various galectins, while others could be relatively specific to a particular galectin (14). Various surface ligands of galectins that are implicated in

\footnotetext{
${ }^{3}$ Human neutrophils express galectin-3 intracellularly while mouse neutrophils do not appear to contain a significant amount of galectin-3.
}

分泌する。これに対し、腹腔内常在性マクロファージ、単球、 肺胞マクロファージは、ガレクチン -3 を細胞質内に貯えたまま でこれを能動的に分泌することはない $(48,50,51)$ 。ガレクチン-3 が “Danger signal” を送ることのできるレクチンであるという 観点から見ると、マクロファージが分化特異的にガレクチン-3 を分泌することは非常に興味深い。感染源である細菌や炎症性 物質が体内に侵入した場合、最初に感染（炎症）巣に浸潤する 白血球はマクロファージではなく好中球である。多くの軽度の 感染（例えば、一部の大腸菌や緑膿菌による急性感染）の場合 は、初期に浸潤した好中球のみで感染を抑えることができる （通常は炎症性マクロファージの組織浸潤は起きない）。興味 深いことに、好中球はは “リーダレス” 分泌経路を利用してガレ クチン-3を分泌することができないため、細胞外で作用し得る ガレクチン-3は極めてわずかになる(51)。好中球とは対照的に、 ガレクチン-3 を分泌することのできる活性化炎症性マクロ ファージ $(48,52,53)$ は、感染が長引いて好中球だけでは感染を抑 えられない場合に感染巣に浸潤してくる(23,54-46)。したがっ て、感染巣へ炎症性マクロファージが浸潤してくる状況とは、 我々の一次防御機構がいわゆる免疫機構に防御への参加を要請 するために “Danger signal” を送っている状況の一例なのであ る。ガレクチン-3 は炎症性マクロファージからは能動的に分泌 されるが腹腔常在性マクロファージからは分泌されない。この ような厳密なガレクチンの分泌調節は、ガレクチンが先天性免 疫に対して “Danger signal” を送る分子であることを明確に示 しているのかもしれない。

\section{D. 免疫反応に関与するガレクチンのリガンド}

ガレクチンが細胞外に放出されると、ガレクチンは細胞表 面のリガンドに結合する(Fig. 2)。ガレクチンは $\beta$-ガラクトシド に結合するレクチンであるが、ガレクチン-10(57)を除くほとん どのガレクチンは、哺乳類細胞に一般的に存在するラクトース やラクトサミン (Gal $\beta 1-3(4) \mathrm{Glc}(\mathrm{NAc}))$ 構造に強い親和性を示す (16-19)。ガレクチンのタンパク質構造研究により、CRD の糖鎖 の結合するポケットの構造がガレクチンにより異なることが明 らかになっている。例えば、ガレクチン-3 はガレクチン-1に比 べて糖鎖の結合するポケットがやや拡張していることが判明し ている(58-60)。このポケットの構造的相違が種々のガレクチン に扔ける糖鎖結合特異性の相違に関連していると考えられる。 非還元末端側のラクトサミンに Gal $\alpha 1-3$, GalNAco1-3, Fuc $\alpha 1-2$ や Neu5Aca2-3 といった置換が入ると、いくつかのガレクチン（例 えばガレクチン-3）への親和性は増すが、他のガレクチンに対 してはその親和性が変化しないか、もしくは減少する（例え ば、ガレクチン-1）(61-63)。したがって、ラクトサミンを含ん でいるリガンドであっても、複数のガレクチンにより認識され るリガンドもあれば特定のガレクチン特異的に認識されるリガ ンドもある(14)。免疫反応に関与していると考えられているガレ

\footnotetext{
${ }^{3}$ ヒト好中球は細胞質にガレクチン-3を発現するが、マウス好中球は有意 な量のガレクチン-3を含有していない。
} 
the regulation of immune responses include $\mathrm{CD} 2,3$ (64), 7 (65), $11 \mathrm{~b}(66), 43,45$ (65), lysosomal associated membrane glycoproteins (LAMP) 1, $2(67,68)$, Thy-1 (69) and laminin (70) in the case of galectin-1. Galectin-3 can bind to CD11b (71), CD32 (Fc $\gamma$ RII) (72), CD49a/CD29 (73), CD66 (74,75), CD98 (71), LAMP $(71,74,76)$, laminin $(62,77-79)$, and fetal tissue-derived but not plasma fibronectin (62).

\section{E. Immunomodulative Activity of Galectins}

Galectins either autocrinely bind back to the cells or paracrinely bind to the adjacent cells once released or secreted. The number of reports on galectins- inducing various activities related to immune responses has overwhelmingly increased in the last decade and it has begun to be difficult to decipher the biological significance of all those activities (16-19). Some clues might rest in the fact that galectins are soluble cytosolic proteins, the extracellular release of which is controlled in various ways, as discussed above. Thus when and where galectins are released or secreted is important in order for them to exert their activities. Another clue would be the fact that soluble galectins could cross-link the surface ligands in at least three different ways (Fig. 2A, B and C), although those ways are not mutually exclusive. Although important, it remains to be established how the cross-linking of ligands on cell surface by galectins preferentially induces one way over the others. In each case, the way galectins mediate the cross-linking appears to determine how the cells respond to extracellular galectin.

\section{F. Cell Adhesion}

One of the initial innate immune responses to infection is leukocyte recruitment to the sites of infection-this process requires strict coordination of cell-cell adhesion. The recruited leukocytes are required to engulf the pathogenic entity by phagocytosis, and release various bactericidal factors, to control the infection, and cytokines, which regulate the subsequent response towards the infection. Leukocyte recruitment to the infected/inflammatory sites involves their movement from the bloodstream to the infected sites through an extravasation process, called emigration or diapedesis. Cell adhesion molecules play a critical role in this recruitment process by mediating the interaction of leukocytes with the vascular endothelial cell barrier separating them from the infected tissue (80-82). As shown in Fig. 3, tight adhesion of leukocytes to the vascular endothelium is required prior to actual diapedesis in order to withstand the shear stress imparted by blood flow (80-82).

Recent reports have demonstrated that galectins promote leukocyte adhesion to extracellular matrices, dendritic cells and the vascular endothelium $(16-19,51,83)$. Galectin-1 mediates the adhesion of splenocytes to the extracellular matrix protein,
クチン-1のリガンドとしては、CD2, CD3(64), CD7(65), CD11b (66), CD43, CD45(65), lysosomal associated membrane glycoproteins (LAMP)-1, -2(67,68), Thy-1(69) やラミニン(70) が挙げられてい る。ガレクチン-3のリガンドとしては、CD11b(71), CD32

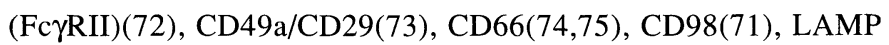
(71,74,76), ラミニン $(62,77-79)$ そして胎児組織由来のフィブロネ クチン(62)が挙げられている。

\section{E. ガレクチンの免疫調節活性}

細胞外に分泌されたガレクチンは、分泌した細胞にオート クリンに結合するかまたはパラクリンに近傍の細胞に結合す る。免疫反応においてガレクチンが誘導する様々な活性に関す る報告の数は過去 10 年間で急増しており、これらすべての活性 が生物学的にどのように免疫機構に組み入れられているかを解 明することが難しくなり始めている(16-19)。謎解きの手がかり のひとつはガレクチンが可溶性の細胞質タンパク質であり、細 胞外への放出が上記の様々な方法で制御されているという事実 にあるのかもしれない。ガレクチンの活性発現にとっては、い つどこでガレクチンが分泌または放出されるかという点が重要 である。他の手がかりとしては、可溶性のガレクチンは互いに 排他的ではない少なくとも 3 通りの様式で細胞表面のリガンド を架橋するという事実が挙げられる(図 2A, B, C)。細胞表面のリ ガンドがこの 3 通りのうちどの様式が優勢になって架橋される かということは重要な点であるが、まだ明らかになっていな い。どの場合についても、ガレクチンが架橋を引き起こす様式 は細胞外のガレクチンに対する細胞の反応を決定するものであ るようだ。

\section{F. 細胞接着}

感染に対する初期の先天性免疫反応の一つに、感染巣への 白血球の浸潤がある。この浸潤過程には細胞接着（細胞-細胞外 マトリックス結合、及び細胞間結合）の厳密な調節が必要であ る。感染巣ヘリクルートされた白血球は、感染体を貪食し、ま た感染を調節するために種々の殺菌性因子やサイトカインを分 泌する。この結果、感染に対して生じる応答を制御することが できる。感染巣または炎症巣へ浸潤する際には、白血球は血管 外遊出(emigration、diapedesis)過程を介して血流中から感染巣へ 移動する。細胞接着因子は感染巣から血管を隔てている血管内 皮細胞層のバリアと白血球との相互作用に介在することによ り、浸潤過程において重要な役割を果たしている(80-82)。図 3 に示すが、血流による剪断ストレス(shear stress)に抵抗するた め、白血球は血管外遊出に先立ち予血管内皮細胞層に固く結 合することが必要である(80-82)。

最近の研究により、ガレクチンが白血球の細胞外マトリッ クス、樹状細胞、および血管内皮細胞への接着に関与すること が明らかにされている (16-19,51,83)。ガレクチン-1は脾蔵由来 細胞のラミニン（細胞外マトリックス）への接着(84)、Tリンパ
${ }^{4}$ Julie Nieminen and Sachiko Sato; unpublished observation, manuscript in preparation
${ }^{4}$ Julie Nieminen and Sachiko Sato; 未発表デー夕、投稿準備中 


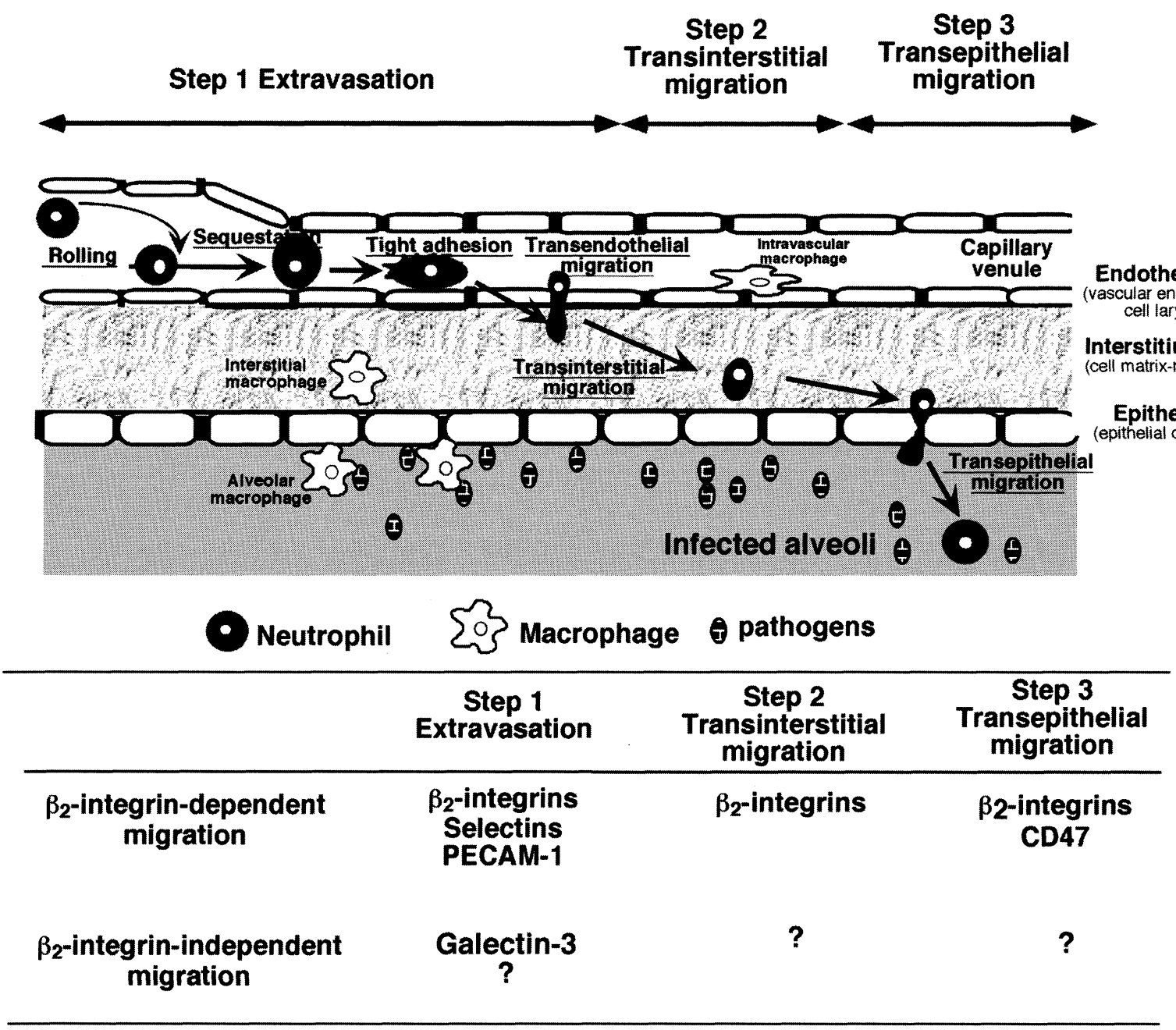

Fig. 3. Neutrophil emigration to infected lungs. Alveolar infection with pathogen induces neutrophil emigration. Infection with some pathogens, such as $E$. coli induces neutrophil emigration, which is mediated by $\beta_{2}$-integrins and selectins, while neutrophil emigration induced by infection with other pathogens, such as $S$. pneumoniae is mediated in a manner independent of $\beta_{2}$-integrins and selectins.

laminin (84), T lymphoblastoid cells to thymic epithelial cells (85) and neutrophils to the endothelium ${ }^{4}$. Galectin-3 can also promote the binding of L-selectin-triggered lymphocytes to dendritic cells (83) and the adhesion of neutrophils to laminin (86), and to the endothelium (51). Such galectin promotion of cell adhesion is induced in at least two ways: (i) direct cross-linking of the surface ligands expressed on the different cells (Fig. 2A) and (ii) the activation of classical cell adhesion molecules integrins through galectins' ligand clustering (Fig. 2B) (18). While data indicate that both mechanisms (Fig. 2A and B) participate to promote leukocyte adhesion, some reports have demonstrated that a significant proportion of galectin promotion of cell adhesion is mediated directly through cross-linking of the cells $(51,86)$. As a matter of fact, galectin promotion of cell adhesion could be observed either at $4{ }^{\circ} \mathrm{C}$, at which temperature cells could not transduce inside-out signal efficiently to activate integrins, or in the absence of cations, which are essential for the integrin activity $(51,86)$. The series of reports employing in
芽球の胸腺上皮細胞への接着 $(85)$ 、好中球の血管内皮細胞への接 着4を仲介する。またガレクチン-3 は L-セレクチンで刺激した リンパ球の樹状細胞への結合(83)、好中球のラミニン(86)や、血 管内皮細胞への結合(51)を仲介する。このようなガレクチンによ る細胞接着は少なくとも2つの機構によって誘導される。(i) 異 なる細胞に発現するガレクチンの細胞表面リガンド同士を架橋 する(図 2A)、(ii) ガレクチンリガンドの凝集を介して典型的な 細胞接着分子であるインテグリンが活性化する(図 2B)(18)。ガ レクチンによる白血球の接着には上記の 2 つの機構が共に関与 することが示されているが、いくつかの報告によれば、ガレク チンによる白血球の接着には細胞間のガレクチンによる直接の 架橋が介在していることが示唆されている $(51 、 86)$ 。実際、ガレ クチンによる細胞接着は細胞がインテグリンの活性化に必要な inside-out シグナルを伝達できない $4{ }^{\circ} \mathrm{Cにおいても、またインテ}$ グリンの活性に必須のカチオンが存在しない条件でも観察され る $(51 、 86)$ 。いずれの機構を介するにしても、様々な in vitro の 
vitro cell adhesion assay have demonstrated that galectin can promote the leukocyte adhesion process.

The pioneer work of Cohneheim in 1877 using intravital microscopy revealed a sequence in leukocyte emigration events (Fig. 3) (87). First leukocytes begin rolling by adhering to the vascular endothelium inside the blood vessel adjacent to the infection/inflammation site. They tether and form tight adhesion with the endothelium, and begin crawling until they reach the intracellular junction of the endothelium, where they insert their pseudopods in between the tightly apposed endothelial cells and "crawl" through — an action termed transendothelial migration. Transinterstitial migration follows as the leukocyte continues migrating through the connective tissues (interstitium). Finally, in transepithelial migration, the leukocyte completely exits by passing through the epithelium into the surrounding tissue where it can participate in the inflammatory response against infection. More than 100 years after the initial observations of leukocyte extravasation, we know that two cell adhesion molecules, selectins and integrins mediate leukocyte recruitment to the affected site in the case of general infected tissues (skin and peritoneal cavity) and acute lung inflammation (80-82,88-91). If those adhesion molecules that are stably integrated to the plasma membrane always play critical roles in leukocyte emigration, how can we implicate the unique soluble adhesion molecules, galectins in the paradigm of leukocyte emigration? If galectins can act as adhesion molecules, when and how is such mediation initiated during inflammation?

The series of studies using mice lacking classical neutrophil adhesion molecules, $\beta_{2}$-integrins ${ }^{5}$ or selectins, and the observation of patients with leukocyte adhesion deficiency-1, who lack the expression of $\beta_{2}$-integrins, have now demonstrated that in some infections and chronic inflammations, those classical adhesion molecules do not necessarily play critical roles in neutrophil emigration (92-97). For example, neutrophils are recruited to the lungs infected with Streptococcal pneumoniae ${ }^{6}$ in a $\beta_{2}$-integrins and selectins independent manner(91-98). Since tight adhesion of neutrophils to the endothelium is essential prior to the emigration from bloodstream, other adhesion proteins are expected to be involved in the process. We have recently suggested that galectin- 3 could act as a unique adhesion molecule in the recruitment of neutrophils in lungs infected by $S$. pneumoniae (51). Upon this infection, galectin-3 is released

${ }^{5} \beta_{2}$-Integrins are the adhesion molecules, which expressed dominantly in peripheral blood neutrophils.

${ }^{6} \mathrm{~S}$. pneumoniae is responsible for the majority of community-acquired pneumonia cases, which account for 40,000 deaths yearly in USA. Despite the availability of numerous antibiotics, (which can in fact render the lungs quasi-sterile) the overall adult mortality rate from streptococcal (pneumococcal) pneumonia remains close to $30 \%$. It is an exaggerated host immune response including neutrophil emigration against pulmonary pneumococcal infections that is blamed, in part, for the high mortality rate of pneumonia $(108,109)$.
系においてガレクチンが白血球の細胞接着の過程を促進するこ とが示されている。

1877 年に Cohneheim は、生きた状態の生体の顕微鏡観察に より白血球の血管遊出の過程を初めて明らかにした(Fig. 3, 87)。 白血球は感染または炎症巣近傍の血管内腔でまず血管内皮細胞 層に接着し、その上を転がる（ローリング）。移動速度の低下 した白血球は、次に血管内皮細胞に密に接着して細胞間接着部 位に到達するまで上皮細胞の上を移動した後、そこで強固に接 着した細胞間に偽足をのばして血管内皮細胞層を通り抜ける (transendothelial migration)。血管外に出た白血球は血管内皮細胞 層下の結合組織を移動し(transinterstitial migration)、最後に外部 に面している上皮細胞層を通りぬける (transepithelial migration) ことにより感染または炎症巣にたどり着き、感染に対する炎症 反応に参加する。白血球の浸潤が初めて観察されてから100年以 上経過した現在、通常の感染巣（皮虐、腹腔）や急性の肺炎症 巣への白血球の浸潤に 2 種類の細胞接着分子、セレクチンとイ ンテグリンが介在していることを我々は知っている(80-82,8891)。もし、構成的に形質膜に発現するこれらの接着分子が常に 白血球の感染巣への浸潤に関わっているとしたならば、可溶性 の接着分子として他に例を見ないこのガレクチンは浸潤過程に どのように関わるのであろうか？もしガレクチンが接着分子と して機能するならば、炎症時のどの時期にどのように関与する のであろうか?

好中球の典型的な接着分子である $\beta_{2}$-インテグリン 5 やセレ クチンを欠損したマウスを用いた研究、また $\beta_{2}$-インテグリンの 発現が欠損している患者(leukocyte adhesion deficiency-1)の観察 から、感染や慢性炎症によっては、典型的な好中球の接着分子 が必ずしもその浸潤に重要な役割を果たしていない場合のある ことが明らかになった (92-97)。例えば、肺炎球菌に感染した肺 (肺炎球菌性肺炎 ${ }^{6}$ ) への好中球の浸潤は、 $\beta_{2}$-インテグリンやセ レクチン非依存的であった(91-98)。血流からの好中球の遊出に 先立ち、好中球が血管内皮細胞層へ強く接着することが必須で ある。したがって、血管外遊出の過程には何らかの接着因子が 関与しているはずである。我々は肺炎球菌性肺炎を起こした肺 への好中球の浸潤に、ガレクチン -3が接着分子として関与する 可能性を示した(51)。ガレクチン-3 はこのような感染時に肺胞 マクロファージなどの肺胞組織から放出される。この放出され

${ }^{5} \beta_{2}$-インテグリンは接着分子である。末梢血好中球に優位に発現してい る。

6アメリカに扔いて年間約 4 万人にのほる市中肺炎の多くは、肺炎球菌 の肺感染によるものである。有効な抗生物質（実際に肺をほとんど殺菌 することができる）が多数利用できる状況にありながら、北米に扔ける 肺炎球菌性肺炎の致死率は30\%近くである。肺炎球菌による感染に対し て好中球の遊走を含む過㮃な免疫反応が生じるが、これが高い致死率の 原因のひとつであると推定されている $(108,109) 。$ 
from alveolar tissues, including resident alveolar macrophages, and our data suggest that the galectin- 3 participates as an adhesion molecule in the initial step of $\beta_{2}$-integrin-independent neutrophil emigration. The regulation of galectin-3-dependent adhesion is apparently unique compared to the regulation of $\beta_{2}-$ integrin activity, which is regulated by the neutrophils insideout signal induced by chemoattractants released and presented on the endothelium at the affected sites $(80,82)$. Without alveolar infection with $S$. pneumoniae, galectin-3 is absent on the surface of neutrophils or endothelial cells, as they cannot secrete galectin-3. Once the $S$. pneumoniae infection is initiated in the lungs, preexisting lung macrophages and possibly other alveolar parenchymal cells secrete galectin-3, which binds immediately to neutrophils and endothelial cells (both express galectin-3 ligands) resulting in neutrophil adhesion.

$\beta_{2}$-Integrin-independent neutrophil emigration is also observed in some peritonitis models and interestingly, the presence of inflammatory macrophages in the peritoneal cavity appears to be prerequisite for the induction of this $\beta_{2}$-Integrin-independent pathway $(99,100)$. As discussed above, such inflammatory peritoneal macrophages, but not resident peritoneal macrophages, actively secrete galectin-3 (48). Thus, it is possible that galectin-3 secreted from inflammatory macrophages plays a role as an adhesion molecule in $\beta_{2}$-integrin-independent neutrophil emigration and it is the secretion of galectin- 3 from differentiated macrophages that initiates neutrophil adhesion. We therefore propose that macrophage release of galectin-3 at the site of inflammation represents a crucial factor in the induction of $\beta_{2}$-integrin-independent, galectin-3-dependent, neutrophil emigration (51).

Recently, galectin-3 null mutant mice were established $(22,23)$. While the results obtained from two independent lines of galectin-3 null mice show some differences in their results, a line of galectin-3 null mice exhibit reduction in neutrophil emigration into the peritoneal cavity in the late stage of inflammation (4 days after induction). In contrast, neutrophil recruitment in the acute stage ( $1-3$ days after induction) is not affected, suggesting a role for macrophage-secreted galectin-3 in neutrophil emigration (23). Characterization of galectin-3 null mice has not been extensively carried out yet. Therefore, it is not yet clear whether the reduced rate of peritoneal neutrophil emigration found in those mice is strictly related to the lack of galectin3 or results from secondary systemic phenotypic alterations, which have now been evoked in some adhesion molecules knockout mice $(93,95,101)$. However, Poirier's group has demonstrated that the robust reduction of neutrophil emigration into the inflamed peritoneal cavities is not the result of a role of galectin-3 in either neutrophil apoptosis or phagocytic uptake by macrophages (23). Thus, considering the reports mentioned above, which suggest that inflammatory macrophages are prerequisite for the induction of $\beta_{2}$-integrin independent emigra-
たガレクチン -3 が $\beta_{2}$-インテグリン非依存性の好中球浸潤の初期 過程において血管内皮細胞への接着分子として機能する可能性 が示されている。 $\beta_{2}$-インテグリンの場合、感染部位の内皮細胞 から分泌、提示された走化性物質によって inside-out シグナルが 入り、これによってインテグリンの活性調節がされる $(80 、 82)$ が、ガレクチン-3 依存性の細胞接着の調節はこれとは明らかに 異なるようである。感染のない状態では好中球や血管内皮細胞 はガレクチン-3を分泌できないため、その細胞表面には存在し ないことになる。肺炎球菌が肺に感染すると、肺常在マク口 ファージや抒そらく他の肺実質細胞などからガレクチン-3が分 泌され、これがすでにリガンドを発現している好中球や血管内 皮細胞に直ちに結合することによって好中球の血管内皮細胞へ の接着が誘導されると考えられる。

$\beta_{2}$-インテグリンに依存しない好中球の浸潤の例が腹膜炎で 報告されている。興味深いことに、腹腔内に炎症性マク口 ファージが存在することは、 $\beta_{2}$-インテグリン非依存的な好中球 の浸潤を誘導するのに不可欠であった(99、100)。先に述べたよう に、腹腔の炎症性マクロファージは腹腔常在性マクロファージ とは異なり、ガレクチン-3を活発に分泌している(48)。したがっ て、炎症性マクロファージから分泌されたガレクチン-3が $\beta_{2}-1$ ンテグリン非依存性の好中球の浸潤に関与する可能性が考えら れる。この場合に好中球の接着を誘導するには、ガレクチン-3 が分化したマクロファージから分泌されることが必要である。 我々は、炎症巣におけるマクロファージのガレクチン -3 分泌が $\beta_{2}$-インテグリン非依存的・ガレクチン - 3 依存的な好中球の血管 外遊出の重要因子であると考えている(51)。

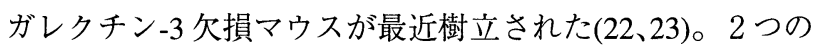
独立な系統でその結果は多少異なるが、片方の系統ではガレク チン-3 欠損マウスで炎症後期（誘導 4 日後）における好中球の 腹腔浸潤が減少していた。好中球浸潤の減少は炎症前期（誘導 1３日後）には見られないことから、マクロファージが分泌す るガレクチン-3が好中球の組織浸潤に関与することが示唆され る(23)。ガレクチン -3 欠損マウスの詳細な解析は始まったばか りなので、このマウスでみられた好中球浸潤の減少がガレクチ ン-3の欠損に直接結びっくものなのか、他の接着分子欠損マウ スで見られるように全身の表現型が二次的に変化したことによ るものかは明らかでない(93、95、101)。しかしながら Poirierのグ ループは、炎症状態の腹腔への好中球の浸潤がこのマウスで強 く抑制されたのは、ガレクチン-3の欠損が好中球のアポトーシ スや、マクロファージによる食食に影響したためではないとい うことを示している(23)。 $\beta_{2}$-インテグリン非依存性の好中球の 浸潤に炎症性のマクロファージが必須であるという報告を考慮 すると、このマウスで炎症性マクロファージからのガレクチン- 
tion of neutrophils, lack of galectin-3 release from inflammatory macrophage in galectin- 3 null mice could affect the integrinindependent neutrophil emigration process. Together, in some infections, it is likely that galectin initiated cross-linking of ligands could directly ligate cells leading to cell-adhesion, which could in turn initiate leukocyte emigration.

\section{G. Surface Galectin-Glycoprotein Lattice, which could Modulate Leukocyte Adhesion and Immunity}

Cell migration comprises successive cycles of adhesion and de-adhesion whereby cells attach to adhesive substances at their migration fronts, then simultaneously extend a pseudopod and release the posterior point of attachment. While various work suggest that galectin acts as an adhesion molecule, there are reports suggesting clearly that galectin acts as an anti-adhesion molecule in the interaction between cells and extracellular matrix (ECM), thereby mediating the de-adhesion process. For example, the presence of galectin-1 inhibits adhesion of IL-2 stimulated $\mathrm{T}$ cells to extracellular matrices, such as laminin, and fibronectin (102). In the case of non-leukocyte cell lines, galectin- 3 and 8 could induce biphasic effects (adhesion-promoting and anti-adhesion) on cell adhesion process depending on the condition. Preincubation of carcinoma cell lines or BHK cells with galectin-3 inhibits cell-adhesion to ECM proteins, laminin, fibronectin and collagen $(62,73)$. The presence of galectin-3 also promotes carcinoma cell migration through ECM, also suggesting that galectin- 3 acts as an anti-adhesive molecule as efficient crawling /migration through matrices comprises successive cycles of adhesion and de-adhesion (103). Galectin-8 inhibits carcinoma cell adhesion to ECM when galectin-8 is not immobilized to the adhesive substances (104). The simplest interpretation for the anti-adhesive activity of galectin is that the cell adhesion process is sterically hindered by a multivalent galectin lattice that is formed by the binding of galectin to either cell adhesion molecules or cell matrices. For example, the ECM protein laminin contains from 13 to $30 \%$ carbohydrate distributed throughout the molecule (105) and cell adhesion molecules, such as Mac-1, a $\beta_{2}$-integrin are heavily glycosylated containing $-20 \%$ carbohydrate in molecular weight-wise. As ECM proteins or integrins contain multiple oligosaccharide chains on the molecule, they are intrinsically multivalent. Cross-linking of bivalent galectin and multivalent ligands leads to the formation of two- and three-dimensional cross-linked complexes, galectin lattices $(106,107)$. Thus, the formation of multivalent galectin-

\footnotetext{
${ }^{7}$ In the case of galectin-8, it is noteworthy that ECM incorporated galectin- 8 does not inhibit cell adhesion but rather that the immobilized galectin- 8 can support cell adhesion.

${ }^{8}$ Recent findings by the group of Al-Awpqti demonstrated that galectin3 mediating oligomerizartion of a ECM protein, hensin is involved in the terminal differentiation of kidney epithelial cells (108). Such a role of ECM incorporated galectin-3 is also suggested in the early stage of kidney tuble formation $(124,125)$.
}

3 の分泌がみられないことが、 $\beta_{2}$-インテグリン非依存性の好中 球の腹腔浸潤過程に影響を及ほした可能性がある。肺炎球菌性 肺炎や慢性腹膜炎などの感染・炎症においては、ガレクチンに よる細胞表面りガンドの架橋が白血球の血管内皮細胞への接着 を直接誘導し、白血球の浸潤を開始させるようである。

G. 白血球の接着や免疫反応を調節することのできるガレクチ ンーリガンド格子 (galectin lattice)

細胞の遊走は細胞接着と脱着との繰り返しである。移動前 方では細胞は接着性の基質に接着して同時に偽足を伸ばすが、 それと同時に移動後方では細胞は接着点から離れている。近年 の種々の報告はガレクチンが接着分子として作用することを示 唆している。その一方で、ガレクチンが細胞と細胞マトリック ス $(\mathrm{ECM})$ との接着を阻害し、その結果としてこれが脱着の過程 に介在するような “抗” 接着分子として作用することを示唆す る報告もある。例えば、ガレクチン-1によってIL-2 で刺激され た $\mathrm{T}$ 細胞の細胞外マトリックス（ラミニンやフィブロネクチン など）への接着が阻害される(102)。白血球系以外の培養細胞株 では、ガレクチン -3 および 8 が細胞接着過程において状況に応 じて二相性作用（接着を促進する、もしくは阻害する）を示 す。上皮細胞性がん細胞株や BHK 細胞をガレクチン-3 とプレ インキュベーションすると、ラミニン、フィブロネクチン、コ ラーゲンなどの ECM タンパク質への接着が阻害される(62、73)。 また、ガレクチン-3 が存在すると ECM を介する上皮細胞性が 儿細胞株の遊走が促進される。細胞が効率よく遊走するために は接着と脱着が繰り返し起こることが必要であるので、この事 実はガレクチン-3が抗接着分子としても機能することを示唆し ている(103)。ガレクチン-8 は接着性の基質に固相化されていな い時には上皮細胞性がん細胞の ECMへの接着を阻害する(104)。 接着阻害活性についての最も簡潔な解釈としては、ガレクチン が接着分子や細胞外マトリクスに結合して多価のガレクチン格 子が形成され、これが細胞接着の過程を立体的に障害する、と いうものが考えられる。例えば、ECM タンパク質のラミニンは 分子量にして13〜30\%の糖鎖を分子全体に有している(105)。 ECMタンパク質やインテグリンは多数の糖鎖を分子内に有して いるため、本質的には多価である。2 価のガレクチンと多価の リガンドによって、2 次元あるいは 3 次元に架橋された複合体 であるガレクチン格子が形成される(106、107)。ECM や細胞表面 にガレクチン一糖タンパク質リガンドからなる多価の格子が形

7ガレクチン-8の場合、ECMに取り込まれたガレクチン-8は細胞接着を阻 害しない。むしろ、固定化されたガレクチン-8は細胞の接着を誘導す る。

${ }^{8} \mathrm{Al}$-Awpqtiグループの最近の報告によれば、ガレクチン-3によって多量 体化するヘンシン（ECMタンパク質の一つ）が腎臓上皮細胞の終末分化 に関与する(108)。ECMに取り込まれたガレクチン-3が初期の腎尿細管の 形成に関わっていることも示唆されている(124,125)。 
glycoprotein ligand lattices either on ECM or cell surfaces could inhibit cell adhesion process through the steric hindrance. It is suggested that the anti-adhesive activities of galectin- 3 or galectin- 8 appear to be evident when the carcinoma cells are either pretreated with the galectin, which is not immobilized to adhesive substances ${ }^{7}(104)$. Thus, those reports may suggest that galectin-glycoprotein lattices on the cell surfaces rather than the $\mathrm{ECM}^{8}$ play critical roles in the anti-adhesive activities of galectins.

The potential roles of the surface multivalent galectin lattices are not limited to the cell migration process and its regulatory role in immune responses has attracted much attention recently (109). Demetrious et al recently suggested that $\mathrm{T}$ cells also contain multivalent galectin-3-glycoprotein lattice on their surface (109). Formation of galectin lattices is partly achieved through the binding of galectin-3 to polylactosamine on $\mathrm{N}$-glycans, synthesis of which are regulated by $\beta 1,6 \mathrm{~N}$ acetylglucosaminyltransferase $\mathrm{V}(\mathrm{Mgat} 5)^{9}$. It is indicated that $\mathrm{T}$ cells from mice deficient in Mgat5 have lower thresholds for T-cell activation and that the hyperactivation of $\mathrm{T}$ cells is induced directly by enhancing $\mathrm{T}$ cell receptor (TCR) clustering. Their data also suggested that the surface multivalent galectin lattices that contain TCR are missing on the surface of T cells from Mgat5 deficient mice. Treatment of T cells from wildtype mice with lactose, which can remove surface galectin lattice, also induces hyperactivation of T cells. As it is expected that galectin lattice could have the potential to restrict the lateral movement of certain receptors involved in immune responses, the presence of a lattice could raise the threshold for ligand-dependent receptor clustering and signal transduction. Thus, hyperactivation of T cells observed in Mgat5 deficient mice is likely caused by the lack of the multivalent two- or threedimensional galectin lattice, which could robustly restrict TCR clustering/movement $(19,109)$.

Galectin-3 was originally found by $\mathrm{Ho}$ and Springer as a surface marker called Mac-2, which is present on the cell surface of inflammatory macrophages (52). They reported that -2 x $10^{5}$ galectin molecules per cell are present on the surface of inflammatory macrophages, suggesting that inflammatory macrophages possess surface galectin- 3 lattices. The robust restriction of the lateral mobility of receptors is not limited to TCR $(110,111)$. First, as discussed above, the presence of surface galectin lattice, which could contain cell adhesion receptors, negatively regulates the cell adhesion cascade. Further, reports that galectin-1 or 3 can inhibit some immune responses suggest that galectin-1 or 3 lattices on the leukocytes could induce such inhibition. Galectin-1 inhibits biosynthesis of tumor necrosis

\footnotetext{
${ }^{9}$ Mgat5 catalyses the addition of $\beta-1,6-$ GlcNAc to $N$-linked glycans in the medial Golgi and the modification by this enzyme leads to the $N$ glycans with two or more polymeric lactosamine repeat units, which show high affinity towards galectins.
}

成されることにより、その立体障害によって細胞接着過程が阻 害されるかもしれない。ガレクチン-3 やガレクチン- 8 の抗接着 活性は、接着性の基質に固相化されていないガレクチンで細胞 をあらかじめ前処理したときに観察されるようである7 (104)。し たがって、ガレクチンの抗接着活性には、マトリックス上のガ レクチン格子ではなく 8 細胞表面上のガレクチン格子による立体 障害が重要な役割を果たしていると考えられる。

細胞表面に形成された多価のガレクチン格子の役割は細胞 の遊走のみに限らない。ガレクチン格子の免疫反応を制御する 役割が最近注目されている(109)。最近、Demetriousらは T 細胞 の表面上にも多価のガレクチン-3 格子が存在することを示した (109)。ガレクチン格子の形成には、ガレクチン-3 と $N$-結合型糖 鎖のポリラクトサミンとの結合が一部関与している。このポリ ラクトサミン鎖の合成は、 $\beta 1,6 N$-アセチルグルコサミニルトラ ンスフェラーゼV(Mgat5) 活性によって制御されている9。Mgat5 欠損マウスの $\mathrm{T}$ 細胞では活性化の闇值が低いため、 $\mathrm{T}$ 細胞受容 体(TCR)の凝集を元進することにより T 細胞の過剩な活性化が 誘導された。このデータから Mgat5 欠損マウスでは $\mathrm{T}$ 細胞表面 の TCR を含む多価のガレクチン格子が欠けていることが示唆さ れた。野生型マウスの T 細胞をラクトース処理すると細胞表面 上のガレクチン格子を除くことができるが、このときにも T 細 胞の過㮃な活性化が観察された。細胞表面のガレクチン格子は 免疫反応に関与する種々の受容体の側方拡散を拘束すると考え られるので、ガレクチン格子の存在はリガンド依存的な受容体 の凝集や、シグナル伝達を起こす閾值を高める。したがって、 Mgat5 欠損マウスの T 細胞で見られた過剩な活性化は、TCR の 凝集や運動を強く制限するガレクチン格子が細胞表面上にない ことによって生じたものと思われる $(19,109) 。$

ガレクチン-3 はもともと Ho や Springerにより炎症性マク ロファージの細胞表面に存在する Mac-2 として見いだされた表 面マーカーである(52)。彼らによれば炎症性マクロファージの細 胞表面には細胞 1 個あたり約 20 万分子の Mac-2 が存在する。 このことから、炎症性マクロファージの細胞表面にはガレクチ ン格子が存在していると考えられる。受容体の側方拡散の拘束 は TCR のみに限定されるわけではない $(110,111) 。$ 既に述べたよ うに、細胞接着分子を含む細胞表面のガレクチン格子は細胞接 着過程を負に制御する。さらにガレクチン-1、-3 が免疫反応の 一部を阻害することから、白血球の細胞表面のガレクチン格子 がそのような阻害に関与しているのかもしれない。ガレクチン.

${ }^{9}$ Mgat5は中間ゴルジ体において $N$-結合型糖鎖にGlcNAcを $\beta 1-6$ 結合で付加 する。この付加の結果、 $N$-結合型糖鎖は最終的には 2 個以上のラクトサ ミンリピートを側鎖にもつ構造になる。ガレクチンの一部はこのラクト サミンリピートに対して高い親和性を持つ。 
factor- $\alpha(\mathrm{TNF} \alpha)$ and interferon- $\gamma(\mathrm{IFN}-\gamma)$ in IL-2 activated T cells (102) or LPS-activated spleen macrophages (112). Galectin-3 also inhibits granulocyte-macrophage colony stimulating factor-induced bone marrow cell proliferation and gene transcription (113). Thus, the presence of surface multivalent galectin lattice on leukocytes could influence immune responses negatively by raising the threshold for ligand-dependent receptor clustering and signal transduction.

As the efficient crawling through tissues for leukocyte emigration comprises successive cycles of adhesion and de-adhesion, roles played by the galectin lattice in cell adhesion process are closely associated with the hypothesis that galectin is a molecule of 'danger signal' to immunity. In contrast, the interrelationship between the robust immune-suppressive activity mediated by the lattice and the potential of galectin as a 'danger signal' may require further discussion in the future. However, if the formation of galectin lattice is regulated by the amount of extracellular unbound galectin, which would be more evident in the end of infection-in other words, when immunity begins to control infection - than in the beginning of infection, such immune suppressive regulation played by the galectin lattice would be beneficial to the integrity of our body. An exaggerated and uncontrolled host immune response against infection is to be blamed, in part, for the high mortality rate and the delay of recovery from infection observed in several infectious diseases.

\section{H. Receptor Clustering by Galectin and Signal Transduc- tion}

Cross-linking of galectin ligands on cell surface also results in the formation of linear (one-dimensional) clusters, inducing signal transduction, some of which are implicated in innate immunity. For example, galectin-1 induces apoptosis of activated T cells (114) and triggers oxidative burst in neutrophils (115). Cross-linking of galectin-3's ligands by galectin-3 leads to the induction of $\mathrm{Ca}^{2+}$ influx in $\mathrm{T}$ lymphocytes and monocytes $(116,117)$, triggering oxidative burst in macrophages and neutrophils $(53,75,118)$, the augmentation of IL-1 production in monocytes (119), the initiation of degranulation in mast cells (120), selective down-regulation of IL-5 expression in eosinophils, peripheral mononuclear cells and $\mathrm{CD}^{+} \mathrm{T}$ cells through the interaction with low affinity IgG receptor (Fc $\gamma I I / C D 32)(121)$. Galectin-3 is a chemoattractant for monocytes, macrophages and endothelial cells $(117,122)$. Galectin-3 could stimulate capillary tube formation and induce angiogenesis, which is closely associated with inflammation (122). Together, extracellularly released galectins trigger several immune reactions through receptor clustering, implying the important role of galectin-3 as a molecule of danger signal in innate immunity against infection.
1 は、IL-2 活性化 T 細胞や LPS で活性化した脾臟のマクロファー

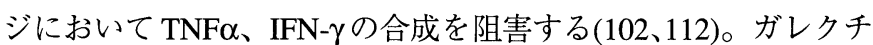
ン-3も同様に、GM-CSF で誘導される骨髄細胞の増殖や遺伝子 転写を阻害する(113)。したがって、白血球細胞表面の多価のガ レクチン格子は、リガンド依存的な受容体の凝集とシグナル伝 達の閾值を上げることで免疫反応を負に制御することができ る。

遊走白血球が組織内で効率よく運動するためには接着と脱 着を繰り返すことが必要である。したがってガレクチン格子の 細胞接着過程に扔ける役割は、ガレクチンが免疫系に “Danger signal”を送ることのできるレクチンである、という仮説に合致 する。これに対し、ガレクチン格子による強い免疫抑制活性 と、免疫反応を誘起する “Danger signal”としての活性がどのよ うに関係するのかという点は今後の検討課題である。しかしな がら、細胞外の未結合のガレクチン量が増えるのは感染初期で はなく終期、すなわち免疫反応が感染を制御し始める頃であ る。ガレクチン格子の形成が細胞外の未結合ガレクチンの量に よって調節されるならば、この免疫抑制調節は我々の体を守る ために有益であろう。なぜなら一部の重篤な感染症でみられる ように、感染に対して免疫反応が調節されぬまま過㮃にはたら くと、これは高い致死率や感染からの回復が遅延する原因のひ とつとなるからである。

\section{H. ガレクチンによる受容体のクラスター形成と情報伝達}

細胞表面におけるガレクチンリガンドの架橋は一次元のク ラスターを形成してシグナル伝達を誘起するが、その一部は先 天性免疫に関与している。例えば、ガレクチン- 1 は活性化 T 細 胞のアポトーシスを誘導し(114)、好中球の活性酸素産生を誘起 する(115)。ガレクチン-3によるリガンドの架橋は、 $\mathrm{T}$ 細胞や単 球の細胞内カルシウム上昇の誘導(116、117)、マクロファージや 好中球の活性酸素産生の誘導(53、75、118)、単球の IL-1 産生増強 (119)、マス卜細胞の脱顆粒反応の誘導(120)、好酸球、末梢血単 核細胞、CD4 陽性 T 細胞において低親和性 IgG 受容体（FcyRII/ CD32）との相互作用を介した IL-5 産生の抑制(121)を誘導する。 さらに、ガレクチン-3 は単球、マクロファージ、及び血管内皮 細胞に対する走化性因子である(117、122)。ガレクチン-3 は、炎 症に伴うであろう毛細血管形成、血管新生を誘導する(122)。こ のように、細胞外に放出されたガレクチンは受容体のクラス ター形成を介して免疫反応を誘導する。この事実は、ガレクチ ン-3が感染に対抗して先天性免疫に “Danger signal”を送るた めの重要な役割を担っていることを示唆する。 


\section{Galectins as Lectinocytokines, which Could Send 'Dan- ger Signals' to Immunity?}

As discussed above, galectins appear to exhibit various roles in immune responses. It is note worthy as well that injection of galectins in vivo could induce leukocyte emigration (117) ${ }^{10}$. Thus, when galectin is released and paracrinely binds to the neighboring cells, it is likely that galectin acts as proinflammatory cytokine. As discussed above, inside cells, galectin is segregated from its glycoconjugate ligands, which are present in the secretory pathway and on the plasma membrane. When the severe infection or chronic infection/inflammation occurs, galectin could either be released from cells damaged by infection or secreted from alveolar resident macrophages in the lung or inflammatory macrophages emigrated in the setting of chronic infection/inflammation. Thus, galectin is released from cells when our defense system should receive several 'danger signals' to initiate immunity. Thus, it is intriguing to propose that galectin acts as a molecule, which can send a 'danger signal' to innate immunity. Interestingly, it has been recently suggested that several proinflammatory cytokine or factors existing in the cytoplasm are also lectins. IL- $1 \beta$, a classical proinflammatory cytokine, which resides in cytoplasm, is a lectin with an affinity for mannose 6-phosphate and its phosphodiester or glycans containing $N$-acetylglucosamine residue and sulfate residue $(12,13)$. Recent reports by Srikrishna et al demonstrate that a heterodimer complex (S100A8/9) of the S100 family (migration inhibitory factor-related protein) recognizes novel carboxylated $\mathrm{N}$-glycans present on the activated endothelial cells (11). S100A8/9 is a proinflammatory protein dimer, which is also retained in the cytoplasm of neutrophils (123). Thus, while further investigations are necessary, the number of cytoplasmic carbohydrate binding proteins which can send danger signals to innate immunity is increasing, implying that those would be categorized as new cytokine group-cytoplasmic lectinocytokine. Galectin should be listed at the top of this new cytokine category.

\section{Acknowledgements}

We would like to express our appreciation to our colleagues and collaborators for discussion and all their support. I would also like to thank Dr. Akira Kobata for letting me learn how sweet sugar could be and Dr. R. Colin Hughes for making me experience the sweet taste of galectin-3.
I. ガレクチンは“Danger signal”を送ることのできるレクチノ サイトカインか?

既に述べてきたように、ガレクチンは免疫反応において 様々な役割を果たしている。注目すべきはin vivoでガレクチン を投与すると白血球の組織浸潤が誘導されることである10 (117)。したがって、細胞外に分泌されて近傍の細胞や組織にパ ラクリンに結合することにより、ガレクチンは炎症誘発性サイ トカインとして作用すると考えられる。既に述べたように、ガ レクチンリガンドは分泌経路や形質膜上に存在するが、一方、 ガレクチンは細胞内に存在するためにこれらリガンドから隔絶 されている。重篤な感染症や慢性感染・炎症が生じると、ガレ クチンは感染によって損傷した細胞から放出されるか、あるい は慢性炎症や感染時に打いて肺常在性マクロファージや病巣に 浸潤した炎症性マクロファージから能動的に分泌される。すな わち、ガレクチンが細胞から放出されるのは、生体防御システ ムが “Danger signal” を先天性免疫に送らなければならない時で ある。従って、ガレクチンは “Danger signal”を送ることのでき る免疫調節因子であると提唱できるのではないだろうか。興味 樑いことに、炎症誘発性のサイトカインや因子の一部が細胞質 に存在し、レクチン活性を有することが近年報告されている。 IL-1及は細胞質に存在する典型的な炎症誘発性サイトカインであ るが、この分子はマンノース 6 リン酸やそのホスホジエステル 体、または $N$-アセチルグルコサミンと硫酸残基を持つ糖鎖に親 和性を示すレクチンである(12,13)。Srikrishnaらは最近、S100 ファミリー(migration inhibitory factor-related protein (MRP))に属 するへテロ二量体 S100A8/9 が活性化血管内皮細胞上に存在する 新規なカルボキシル化 $N$-結合型糖鎖を認識するレクチンである ことを示した(11)。S100A8/9 は炎症誘発活性を持つタンパク質 で、好中球の細胞質に保持されている(123)。さらなる検討が必 要である一方、実際には、細胞質内に存在し、先天性免疫に “Danger signal”を送ることのできる糖鎖結合タンパク質が次々 と発見されている。すなわち、これらの分子を新しいサイトカ イン群一細胞質レクチノサイトカインとして分類することがで きるのではないだろうか。その場合、ガレクチンはレクチノサイ トカインのリストのトップに位置づけられるべきものである。

謝 辞

この場を借りて、共同研究者、そして様々なサポートや アドバイスをいただきました研究者に改めて感謝したいと思い ます。また、私に糖鎖生物学がいかにすばらしい(sweet)ものか を教えて下さった木幡陽先生、そしてガレクチン-3の甘い味を 教えてくださった Dr. R. Colin Hughesに涾く感謝します。

\section{References}

1. Janeway, C. A., Jr. (1989) Cold Spring Harb. Symp. Quan.t Biol. 54, 1-13

2. Matzinger, P. (1994) Annu. Rev. Immunol. 12, 991-1045

3. Medzhitov, R., and Janeway, C. A., Jr. (2002) Science 296, 298-300

4. Hoffmann, J. A., Kafatos, F. C., Janeway, C. A., and Ezekowitz, R. A. (1999) Science 284, 1313-1318

5. Matzinger, P. (1998) Semin. Immunol. 10, 399-415

6. Matzinger, P. (2002) Science 296, 301-305

7. Yi, A. K., Tuetken, R., Redford, T., Waldschmidt, M., Kirsch, J., and Krieg, A. M. (1998) J. Immunol. 160, 4755-4761

8. Wallin, R. P., Lundqvist, A., More, S. H., von Bonin, A., Kiessling, R., and Ljunggren, H. G. (2002) Trends Immunol. 23, 130-135

9. Graca-Souza, A. V., Arruda, M. A., de Freitas, M. S., Barja-Fidalgo, C., and Oliveira, P. L. (2002) Blood 99, 4160-4165 
10. Bertini, R., Howard, O. M., Dong, H. F., Oppenheim, J. J., Bizzarri, C., Sergi, R., Caselli, G., Pagliei, S., Romines, B., Wilshire, J. A., Mengozzi, M., Nakamura, H., Yodoi, J., Pekkari, K., Gurunath, R., Holmgren, A., Herzenberg, L. A., and Ghezzi, P. (1999) J. Exp. Med. 189, 1783-1789

11. Srikrishna, G., Panneerselvam, K., Westphal, V., Abraham, V., Varki, A., and Freeze, H. H. (2001) J. Immunol. 166, 4678-4688

12. Fukushima, K., Hara-Kuge, S., Ohkura, T., Seko, A., Ideo, H., Inazu, T., and Yamashita, K. (1997) J. Biol.Chem. 272, 10579-10584

13. Tandai-Hiruma, M., Endo, T., and Kobata, A. (1999) J. Biol.Chem. 274, 4459-4466

14. Perillo, N. L., Marcus, M. E., and Baum, L. G. (1998) J. Mol. Med. 76, $402-4012$

15. Cooper, D. N., and Barondes, S. H. (1999) Glycobiology 9, 979-984

16. Rabinovich, G. A. (1999) Cell Death Differ. 6, 711-721

17. Liu, F. T. (2000) Clin. Immunol. 97, 79-88

18. Hughes, R. C. (2001) Biochimie 83, 667-676

19. Lowe, J. B. (2001) Cell 104, 809-812

20. Hughes, R. C. (1999) Biochim. Biophys. Acta 1473, 172-185

21. Yu, F., Finley, R. L., Jr., Raz, A., and Kim, H. R. (2002) J. Biol.Chem. 277, 15819-15827

22. Hsu, D. K., Yang, R. Y., Pan, Z., Yu, L., Salomon, D. R., Fung-Leung, W. P., and Liu, F. T. (2000) Am. J. Pathol. 156, 1073-1083

23. Colnot, C., Ripoche, M. A., Milon, G., Montagutelli, X., Crocker, P. R., and Poirier, F. (1998) Immunology 94, 290-296

24. Barondes, S. H., Castronovo, V., Cooper, D. N., Cummings, R. D., Drickamer, K., Feizi, T., Gitt, M. A., Hirabayashi, J., Hughes, C., Kasai, K., and et al. (1994) Cell 76, 597-598

25. Yang, R. Y., Hsu, D. K., Yu, L., Ni, J., and Liu, F. T. (2001) J. Biol.Chem. 276, 20252-20260

26. Visegrady, B., Than, N. G., Kilar, F., Sumegi, B., Than, G. N., and Bohn, H. (2001) Protein Eng. 14, 875-880

27. Dunphy, J. L., Barcham, G. J., Bischof, R. J., Young, A. R., Nash, A., and Meeusen, E. N. (2002) J. Biol.Chem. 277, 14916-14924

28. Pace, K. E., Lebestky, T., Hummel, T., Arnoux, P., Kwan, K., and Baum, L. G. (2002) J. Biol.Chem. 277, 13091-13098

29. Hirabayashi, J., and Kasai, K. (1993) Glycobiology 3, 297-304

30. Cherayil, B. J., Weiner, S. J., and Pillai, S. (1989) J. Exp. Med. 170, 1959-1972

31. Massa, S. M., Cooper, D. N., Leffler, H., and Barondes, S. H. (1993) Biochemistry 32, 260-267

32. Hsu, D. K., Zuberi, R. I., and Liu, F. T. (1992) J. Biol.Chem. 267, 14167-14174

33. Barboni, E. A., Bawumia, S., Henrick, K., and Hughes, R. C. (2000) Glycobiology 10, 1201-1208

34. Gorski, J. P., Liu, F. T., Artigues, A., Castagna, L. F., and Osdoby, P. (2002) J. Biol.Chem. 277, 18840-18848

35. Wilson, T. J., Firth, M. N., Powell, J. T., and Harrison, F. L. (1989) Biochem. J. 261, 847-852

36. Cooper, D. N., and Barondes, S. H. (1990) J. Cell Biol. 110, 1681-1691

37. Rubartelli, A., Cozzolino, F., Talio, M., and Sitia, R. (1990) EMBO J. 9, 1503-1510

38. Muesch, A., Hartmann, E., Rohde, K., Rubartelli, A., Sitia, R., and Rapoport, T. A. (1990) Trends Biochem. Sci. 15, 86-88

39. Andrei, C., Dazzi, C., Lotti, L., Torrisi, M. R., Chimini, G., and Rubartelli, A. (1999) Mol. Biol. Cell 10, $1463-1475$

40. Friesel, R., and Maciag, T. (1999) Thromb. Haemost. 82, 748-754

41. Mignatti, P., Morimoto, T., and Rifkin, D. B. (1992) J. Cell Physiol. 151, 81-93

42. Florkiewicz, R. Z., Majack, R. A., Buechler, R. D., and Florkiewicz, E. (1995) J. Cell Physiol. 162, 388-399

43. Rubartelli, A., Bajetto, A., Allavena, G., Wollman, E., and Sitia, R. (1992) J. Biol.Chem. 267, 24161-24164

44. Rammes, A., Roth, J., Goebeler, M., Klempt, M., Hartmann, M., and Sorg, C. (1997) J. Biol.Chem. 272, 9496-9502

45. Dinarello, C. A. (1996) Blood 87, 2095-147

46. Chabot, S., Kashio, Y., Seki, M., Shirato, Y., Nakamura, K., Nishi, N., Nakamura, T., Matsumoto, R., and Hirashima, M. (2002) Glycobiology 12, 111-8

47. Lutomski, D., Fouillit, M., Bourin, P., Mellottee, D., Denize, N., Pontet, M., Bladier, D., Caron, M., and Joubert-Caron, R. (1997) Glycobiology 7, 1193-9

48. Sato, S., and Hughes, R. C. (1994) J. Biol.Chem. 269, 4424-4430

49. Sato, S., and Hughes, R. C. (1994) Eur. J. Immunol. 24, 216-221

50. Kasper, M., and Hughes, R. C. (1996) J. Pathol. 179, 309-316

51. Sato, S., Ouellet, N., Pelletier, I., Simard, M., Rancourt, A., and Bergeron, M. G. (2002) J. Immunol. 168, 1813-1822

52. Ho, M.-K., and Springer, T. A. (1982) J. Immunol. 128, 1221-1227

53. Liu, F. T., Hsu, D. K., Zuberi, R. I., Kuwabara, I., Chi, E. Y., and Henderson, W. R. (1995) Am. J. Pathol. 147, 1016-1028

54. Louahed, J., Zhou, Y., Maloy, W. L., Rani, P. U., Weiss, C., Tomer, Y., Vink, A., Renauld, J., Van Snick, J., Nicolaides, N. C., Levitt, R. C., and Haczku, A. (2001) Blood 97, 1035-1042

55. Bergeron, Y., Ouellet, N., Deslauriers, A. M., Simard, M., Olivier, M., and Bergeron, M. G. (1998) Infect. Immun. 66, $912-922$

56. Fillion, I., Ouellet, N., Simard, M., Bergeron, Y., Sato, S., and Bergeron, M. G. (2001) J. Immunol. 166, 7353-7361

57. Swaminathan, G. J., Leonidas, D. D., Savage, M. P., Ackerman, S. J., and Acharya, K. R. (1999) Biochemistry 38, 13837-13843

58. Lobsanov, Y. D., Gitt, M. A., Leffler, H., Barondes, S. H., and Rini, J. M. (1993) J. Biol.Chem. 268, 27034-27038

59. Seetharaman, J., Kanigsberg, A., Slaaby, R., Leffler, H., Barondes, S. H., and Rini, J. M. (1998) J. Biol.Chem. 273, 13047-13052

60. Henrick, K., Bawumia, S., Barboni, E. A., Mehul, B., and Hughes, R. C. (1998) Glycobiology 8, 45-57

61. Sparrow, C. P., Leffler, H., and Barondes, S. H. (1987) J. Biol.Chem. 262, 7383-90

62. Sato, S., and Hughes, R. C. (1992) J. Biol.Chem. 267, 6983-6990

63. Ahmed, H., Állen, H. J., Sharma, A., and Matta, K. L. (1990) Biochemistry 29, 5315-5319

64. Walzel, H., Blach, M., Hirabayashi, J., Kasai, K. I., and Brock, J. (2000) Glycobiology 10, 131-140

65. Pace, K. E., Lee, C., Stewart, P. L., and Baum, L. G. (1999) J. Immunol. 163, 3801-3811

66. Avni, O., Pur, Z., Yefenof, E., and Baniyash, M. (1998) J. Immunol. 160, 6151-6158

67. Do, K. Y., Smith, D. F., and Cummings, R. D. (1990) Biochem. Biophys. Res. Commun. 173, 1123-1128

68. Ohannesian, D. W., Lotan, D., and Lotan, R. (1994) Cancer Res. 54, 5992-6000

69. Symons, A., Cooper, D. N., and Barclay, A. N. (2000) Glycobiology 10, 559-63

70. Zhou, Q., and Cummings, R. D. (1990) Arch. Biochem. Biophys. 281, 27-35 
71. Dong, S., and Hughes, R. C. (1997) Glycoconj. J. 14, 267-274

72. Cortegano, I., Pozo, V., Cardaba, B., Arrieta, I., Gallardo, S., Rojo, M., Aceituno, E., Takai, T., Verbeek, S., Palomino, P., Liu, F. T., and Lahoz, C. (2000) Glycobiology 10, 237-42

73. Ochieng, J., Leite-Browning, M. L., and Warfield, P. (1998) Biochem. Biophys. Res. Commun. 246, 788-791

74. Ohannesian, D. W., Lotan, D., Thomas, P., Jessup, J. M., Fukuda, M., Gabius, H. J., and Lotan, R. (1995) Cancer Res. 55, 2191-2199

75. Yamaoka, A., Kuwabara, I., Frigeri, L. G., and Liu, F. T. (1995) J. Immunol. 154, 3479-3487

76. Inohara, H., and Raz, A. (1994) Biochem. Biophys. Res. Commun. 201, 1366-1375

77. Woo, H.-J., Shaw, L. M., Messier, J. M., and Mercurio, A. M. (1990) J. Biol. Chem. 265, 7097-7099

78. Cherayil, B. J., Chaitovitz, S., Wong, C., and Pillai, S. (1990) Proc. Natl. Acad. Sci. U S A 87, 7324-7328

79. Ochieng, J., and Warfield, P. (1995) Biochem. Biophys. Res. Commun.217, 402-406

80. Butcher, E. C., and Picker, L. J. (1996) Science 272, 60-66

81. Carlos, T. M., and Harlan, J. M. (1994) Blood 84, 2068-2101

82. Springer, T. A. (1994) Cell 76, 301-314

83. Swarte, V. V., Mebius, R. E., Joziasse, D. H., Van den Eijnden, D. H., and Kraal, G. (1998) Eur. J. Immunol. 28, 2864-2871

84. Ramkumar, R., and Podder, S. K. (2000) J Mol Recognit 13, 299-309

85. Baum, L. G., Pang, M., Perillo, N. L., Wu, T., Delegeane, A., Uittenbogaart, C. H., Fukuda, M., and Seilhamer, J. J. (1995) J. Exp. Med. 181, 877-887

86. Kuwabara, I., and Liu, F. T. (1996) J. Immunol. 156, 3939-3944

87. Cohnheim, J. (1889) Lectures on general pathology: A handbook for practitioners and students (London: the New Sydenham Society)

88. Doerschuk, C., M., Quinlan, W., M., Doyle N., A., Bullard, D., C., Vestweber, D., Jones, M., L., Takei, F., Ward, P., A., and Beaudet, A., L. (1996) J. Immunol. 157, 4609-4614

89. Mulligan, M. S., Wilson, G. P., Todd, R. F., C.W., S., Anderson, D. C., Varani, J., Issekutz, T. B., Miyasaka, M., Tamatani, T., Rusche, J. R., Vaporciyan, A. A., and Ward, P. A. (1993) J. Immunol. 150, 2407-2417

90. Mulligan, M. S., Paulson, J. C., De-Frees, S., Zheng, Z. L., Lowe, J. B., and Ward, P. A. (1993) Nature 364, $149-151$

91. Doyle, N. A., Bhagwan, S. D., Meek, B. B., Kutkoski, G. J., Steeber, D. A., Tedder, T. F., and Doerschuk, C. M. (1997) J. Clin. Invest. 99, 526-533

92. Mizgerd, J., P., Meek, B., B., Kutkoski, G., J., Bullard, D., C., Beaudet, A., L., and Doerschuk, C., M. (1996) J. Exp. Med. 184, 639-645

93. Mizgerd, J. P., Horwitz, B. H., Quillen, H. C., Scott, M. L., and Doerschuk, C. M. (1999) J. Immunol. 163, 995-999

94. Doerschuk, C., M., Winn, R., K., Coxson, H., O., and Harlan, J., M. (1990) J. Immunol. 144, 2327-2333

95. Mizgerd, J., P., Kubo, H., Kutkoski, G., J., Bhagwan, S., D., Scharffetter-Kochanek, K., Beaudet, A., L., and Doerschuk, C., M. (1997) J. Exp. Med. 186, 1357-1364

96. Hogg, J. C., and Doerschuk, C. M. (1995) Annu. Rev. Physiol. 57, 97-114

97. Kumasaka, T., Doyle, N. A., Quinlan, W. M., Graham, L., and Doerschuk, C. M. (1996) Am. J. Pathol. 148, 1297-1305

98. Bullard, D. C., Qin, L., Lorenzo, I., Quinlin, W. M., Doyle, N. A., Bosse, R., Vestweber, D., Doerschuk, C. M., and Beaudet, A. L. (1995) J. Clin. Invest. 95, 1782-1788

99. Mileski, W., Harlan, J., Rice, C., and Winn, R. (1990) Circ. Shock 31, 259-267

100. Winn, R. K., and Harlan, J. M. (1993) J. Clin. Invest. 92, 1168-1173

101. Collins, R. G., Jung, U., Ramirez, M., Bullard, D. C., Hicks, M. J., Smith, C. W., Ley, K., and Beaudet, A. L. (2001) Blood 98, 727-735

102. Rabinovich, G. A., Ariel, A., Hershkoviz, R., Hirabayashi, J., Kasai, K. I., and Lider, O. (1999) Immunology 97, 100-106

103. Le Marer, N., and Hughes, R. C. (1996) J. Cell. Phys. 168, 51-58

104. Levy, Y., Arbel-Goren, R., Hadari, Y. R., Eshhar, S., Ronen, D., Elhanany, E., Geiger, B., and Zick, Y. (2001) J. Biol.Chem. 276, 3128531295

105. Fujiwara, S., Shinkai, H., Deutzmann, R., Paulsson, M., and Timpl, R. (1988) Biochem J 252, 453-461

106. Lee, R. T., and Lee, Y. C. (2000) Glycoconj J 17, 543-551

107. Sacchettini, J. C., Baum, L. G., and Brewer, C. F. (2001) Biochemistry 40, 3009-15

108. Hikita, C., Vijayakumar, S., Takito, J., Erdjument-Bromage, H., Tempst, P., and Al-Awqati, Q. (2000) J. Cell Biol. 151, 1235-1246

109. Demetriou, M., Granovsky, M., Quaggin, S., and Dennis, J. W. (2001) Nature 409, 733-739

110. Vespa, G. N., Lewis, L. A., Kozak, K. R., Moran, M., Nguyen, J. T., Baum, L. G., and Miceli, M. C. (1999) J. Immunol. 162, 799-806

111. Chung, C. D., Patel, V. P., Moran, M., Lewis, L. A., and Carrie Miceli, M. (2000) J. Immunol. 165, 3722-3729

112. Santucci, L., Fiorucci, S., Cammilleri, F., Servillo, G., Federici, B., and Morelli, A. (2000) Hepatology 31, 399-406

113. Krugluger, W., Frigeri, L. G., Lucas, T., Schmer, M., Forster, O., Liu, F. T., and Boltz-Nitulescu, G. (1997) Immunobiology 197, 97-109

114. Perillo, N. L., Pace, K. E., Seilhamer, J. J., and Baum, L. G. (1995) Nature 378, 736-739

115. Almkvist, J., Dahlgren, C., Leffler, H., and Karlsson, A. (2002) J. Immunol. 168, 4034-4041

116. Dong, S., and Hughes, R. C. (1996) FEBS Lett 395, 165-169

117. Sano, H., Hsu, D. K., Yu, L., Apgar, J. R., Kuwabara, I., Yamanaka, T., Hirashima, M., and Liu, F. T. (2000) J. Immunol. 165, $2156-2164$

118. Karlsson, A., Follin, P., Leffler, H., and Dahlgren, C. (1998) Blood 91, 3430-3438

119. Jeng, K. C., Frigeri, L. G., and Liu, F. T. (1994) Immunol. Lett. 42, 113-116

120. Frigeri, L. G., Zuberi, R. I., and Liu, F.-T. (1993) Biochemistry 32, 7644-7649

121. Cortegano, I., del Pozo, V., Cardaba, B., de Andres, B., Gallardo, S., del Amo, A., Arrieta, I., Jurado, A., Palomino, P., Liu, F. T., and Lahoz, C. (1998) J. Immunol. 161, 385-389

122. Nangia-Makker, P., Honjo, Y., Sarvis, R., Akahani, S., Hogan, V., Pienta, K. J., and Raz, A. (2000) Am. J. Pathol. 156, 899-909

123. Kerkhoff, C., Klempt, M., and Sorg, C. (1998) Biochim. Biophys. Acta 1448, 200-211

124. Bao, Q., Hughes, R. C. (1995) J. Cell. Sci. 108, 2791-800

125. Bao, Q., and Hughes, R. C. (1999) Glycobiology 9, 489-495

Received on June 28, 2002, accepted on August 6, 2002 


\section{Profile of the Authors}

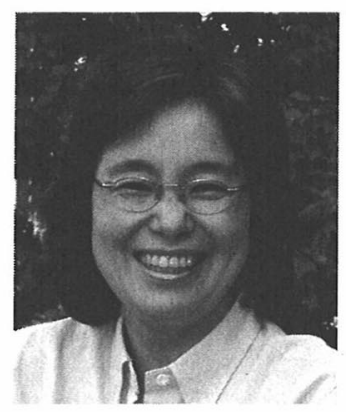

Sachiko Sato graduated in Pharmaceutical Science at Chiba University and obtained her Ph.D. from Tokyo University (Drs. A. Kobata, and S. Takasaki). She had worked in the laboratory of Dr. R. Colin Hughes (research on galectin-3) at MRC; National Institute for Medical Research, Mill Hill, London, U. K., as a post-doctoral fellow in the laboratory of Dr. R. Ron Kopito (ER quality control system), Stanford University, USA and in the laboratory of Dr. M. G. Bergeron (Infectious diseases), Laval University, Canada. In 1999, she started a glycobiology laboratory in the Research Centre for Infectious Disease, Laval University Medical Centre, Québec, Canada and since then she has been a principle investigator and assistant professor in Laval University. She has been currently investigating the roles of galectins in innate immunity against infections. She is also interested in the intracellular roles of glycoconjugates. She loves to see Japanese animations produced by $\mathrm{H}$. Miyazaki and chat about anything. 